\title{
KOMPARÁCIA VYBRANÝCH KOMERČNÝCH BÁNK V SR
}

\author{
Lucia Madleňáková*
}

Úvod

Problematika poskytovania bankových služieb s narastajúcimi požiadavkami zákazníkov a zvýšenou aktivitou konkurenčných spoločností je čoraz viac obsiahlejšia. Pre dosiahnutie výhodnejšieho postavenia na trhu a uspokojenie zákazníka je nevyhnutné zvolit' primeranú koncepciu a stratégiu bankového subjektu. Rozhodovanie sa individuálneho klienta o výbere vhodného bankového domu je závislé od jeho požiadaviek a preferencií, ktoré sa vzt’ahujú najmä na miestnu a časovú dostupnost' k službám a často krát sa premietajú a závisia aj od sumy bankových poplatkov či objemu finančných nákladov, ktoré musí klient uhradit' za požadované služby.

Slovenská banková asociácia pravidelne už pät' rokov uskutočňuje v spolupráci so spoločnost'ou Scott and Rose analýzu porovnávajúcu priemerné ročné náklady na vedenie a správu bežného účtu v piatich krajinách strednej Európy. V podmienkach slovenského bankového sektora bola analýza vykonaná na základe modelu správania sa priemerného klienta slovenských bánk a skladá sa z nasledujúcich položiek: priemerný zostatok na účte, výpisy z účtu, hotovost', platby tuzemské, zriadenie a zrušenie trvalého príkazu, spôsob komunikácie s bankou a platobné karty. [3] Celkové náklady na vedeniu účtu sa skladajú zo siedmych pripočítatel'ných a jednej odpočítatel'nej položky: správa účtu (paušálny poplatok za vedenie účtu), výnosy z úrokov, operácie s hotovost'ou na pobočke, platby (bezhotovostné domáce transakcie), správa trvalých príkazov, výber hotovosti z bankomatov, vydanie platobnej karty, správa internetbankingu. Nakol'ko ide o modelové správanie sa priemerného slovenského klienta, analýzy naznačujú kol'ko zaplatí modelový klient v priemere v danej krajine pri tom istom správaní. [3]

\section{Porovnanie ročných nákladov klienta na správu a vedenie bežných účtov v SR a zahraničí}

Podl'a výsledkov prieskumu Slovenskej bankovej asociácie (d’alej SBA) sa v roku 2009 ročné náklady na vedenie a správu bežného účtu podl'a správania sa modelového klienta v priemere pohybovali v rozpätí od 46,6 EUR až 65,3 EUR. Najnižšie náklady klienta boli po prvý krát vypočítané v pol’ských bankách, druhé najnižšie v slovenských bankách a najvyššie náklady zaplatí klient v českých bankách.

\footnotetext{
* Ing. Lucia Madleňáková, PhD., Žilinská univerzita v Žiline, Fakulta Prevádzky a ekonomiky dopravy a spojov, Katedra spojov, Univerzitná 1, 01026 Žilina tel.: +421/41/513 3125, fax: +421/41/56 55615

e-mail: Lucia.Madlenakova@fpedas.uniza.sk
} 


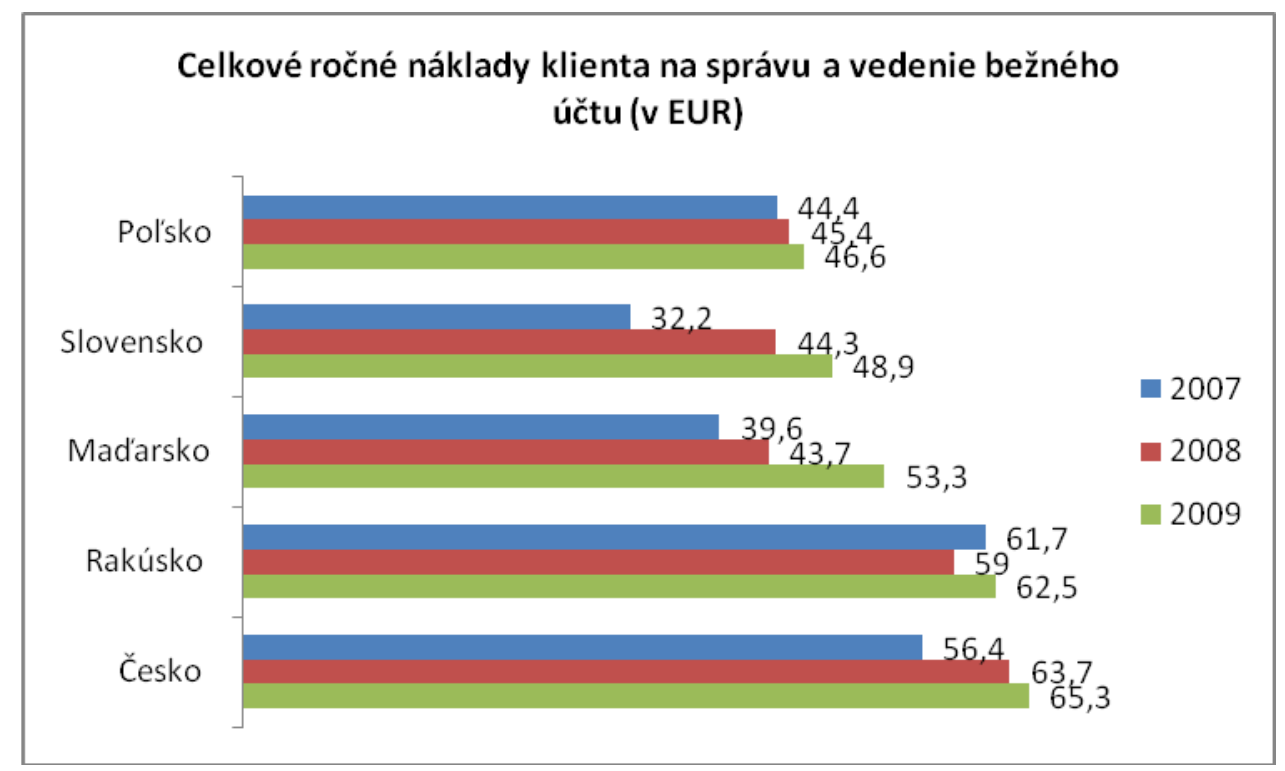

Obrázok 1 Ročné náklady klienta na správu a vedenie účtu vo vybraných krajinách

(Zdroj: Slovenská banková asociácia: Porovnanie ročných nákladov na vedenie bežných účtov vo vybraných krajinách za rok 2009)

Najvýraznejšiu čast' nákladov vo všetkých sledovaných krajinách v roku 2009 (výnimkou je Mad’arsko) tvoril paušálny poplatok za správu a vedenie účtu. Táto situácia je daná tzv. paušálnym modelom spoplatňovania, kedy do jedného poplatku sú zahrnuté základné služby, resp. sú kompenzované niektoré nulové poplatky (napr. výber z vlastného bankomatu, elektronické bankovníctvo a pod.). Tento model je uplatňovaný napr. v Rakúsku a približuje sa knemu aj Slovensko a Česko. Naopak v prípade mad’arských bánk sú jednotlivé služby (položky) spoplatňované zvlášt', a preto majú približne rovnaký podiel na celkových nákladoch a poplatkoch súvisiacich s vedením a spravovaním účtu klienta. [3]

Tabul'ka 1 Ročné náklady a poplatky klienta v jednotlivých krajinách podl’a položiek za rok 2009 (EUR)

\begin{tabular}{|l|c|c|c|c|c|}
\hline & Rakúsko & Česko & Mad'arsko & Pol'sko & Slovensko \\
\hline Platby & 1,57 & 12,30 & 14,06 & 11,90 & 5,13 \\
\hline Správa internetbankingu & 0,00 & 5,72 & 2,43 & 2,40 & 2,35 \\
\hline Správa trvalých príkazov & 0,56 & 0,33 & 0,02 & 0,15 & 0,31 \\
\hline Správa účtu & 56,29 & 30,77 & 14,60 & 20,20 & 29,94 \\
\hline Operácie s hotovost'ou na pobočke & 2,37 & 3,83 & 2,89 & 0,00 & 3,03 \\
\hline Výber hotovosti z bankomatov & 0,00 & 6,04 & 15,61 & 5,57 & 5,98 \\
\hline Vydanie platobnej karty & 5,02 & 6,66 & 5,99 & 6,57 & 3,06 \\
\hline Výnosy z úrokov & $-3,34$ & $-0,36$ & $-2,31$ & $-0,18$ & $-0,91$ \\
\hline Celkové ročné náklady & $\mathbf{6 2 , 4 7}$ & $\mathbf{6 5 , 2 8}$ & $\mathbf{5 3 , 3 0}$ & $\mathbf{4 6 , 6 2}$ & $\mathbf{4 8 , 8 8}$ \\
\hline
\end{tabular}

(Zdroj: Slovenská banková asociácia: Porovnanie ročných nákladov na vedenie bežných účtov vo vybraných krajinách za rok 2009)

Z uskutočnených analýz SBA je zrejmé, že Slovensko stále patrí v stredoeurópskom regióne medzi krajiny s nízkymi nákladmi na vedenie a správu bežného účtu. Tradične mu v rámci analýz uskutočňovaných SBA patrí druhé miesto. Žiadna zo sledovaných položiek nie je najdrahšia a v prípade vydania platobných kariet má Slovensko najnižšiu cenovú hladinu a nízke poplatky za zrealizované domáce platby a používanie služieb internetbankingu. Naopak výrazný prepad bol zaznamenaný v prípade Mad'arska, ktoré sa posunulo oproti minulému roku z prvého až na tretie miesto. 


\section{Komparácia vybraných slovenských bankových subjektov podl’a vybraných atribútov}

Výber bankového produktu z pohl'adu ekonomickej výhodnosti môže byt' náročný a to ako pri výbere bežného účtu resp. balíka služieb, ale i úverových produktov. Porovnanie vybraných slovenských bankových subjektov bolo realizované na základe modelového klienta, charakter ktorého zodpovedal priemernému správaniu sa bežného súkromného klienta slovenských bánk. Porovnávané atribúty zodpovedali aktivitám klienta pri využívaní bežného účtu a výrazne kopírovali atribúty použité v analýze realizovanej SBA.

Základný modelový príklad použitý pre porovnávanie vybraných bánk:

- Počet prijatých platieb za mesiac

- Počet výberov z vlastného bankomatu za mesiac

- Počet výberov z vlastného bankomatu za mesiac

- Počet trvalých príkazov za mesiac

- Počet inkasných príkazov za mesiac

- Počet elektronických platieb jednorazových za mesiac

- Bezhotovostná platba kartou za mesiac

V každej z vybraných komerčných bánk bol pre porovnanie vybraný balík služieb, ktorý čo najviac zodpovedal vybraným atribútom modelového klienta, pričom do úvahy boli brané aj d’alšie charakteristiky ako náklady spojené so zriadením účtu, vydaním platobnej karty, povolené prečerpanie a mesačné zasielanie výpisu poštou.

Tabul'ka 2 Porovnanie mesačných poplatkov a nákladov modelového klienta na vedenie osobných účtov vybraných slovenských bánk

\begin{tabular}{|c|c|c|c|c|c|c|c|}
\hline & 登 & 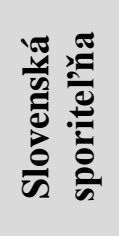 & 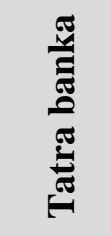 & 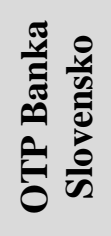 & 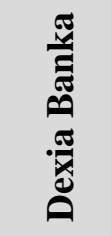 & 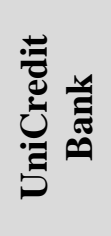 & 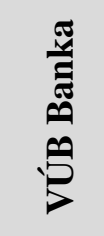 \\
\hline Prijaté platby & $\checkmark$ & $\checkmark$ & $\sqrt{ }$ & $\checkmark$ & $\checkmark$ & $\checkmark$ & $\checkmark$ \\
\hline Výber z bankomatu & $\checkmark$ & $\checkmark$ & $\checkmark$ & $\checkmark$ & $\checkmark$ & $\checkmark$ & $\checkmark$ \\
\hline Trvalý príkaz & $\checkmark$ & $\checkmark$ & $\checkmark$ & $\checkmark$ & $\checkmark$ & $\checkmark$ & $\checkmark$ \\
\hline Inkasný príkaz & $\checkmark$ & $\checkmark$ & $\checkmark$ & $\checkmark$ & $\checkmark$ & $\checkmark$ & $\checkmark$ \\
\hline Platby cez IB & $\checkmark$ & $\checkmark$ & $\checkmark$ & $\checkmark$ & $\checkmark$ & $\checkmark$ & $\checkmark$ \\
\hline $\begin{array}{l}\text { Bezhotovostné platby } \\
\text { platobnou kartou }\end{array}$ & $\checkmark$ & $\checkmark$ & $\checkmark$ & $\checkmark$ & $\checkmark$ & $\checkmark$ & $\checkmark$ \\
\hline Zriadenie účtu & $\checkmark$ & $\checkmark$ & $\checkmark$ & $\checkmark$ & $\checkmark$ & $\checkmark$ & $\checkmark$ \\
\hline Vydanie platobnej karty & $\checkmark$ & $\checkmark$ & $\checkmark$ & $\checkmark$ & $\checkmark$ & $\checkmark$ & $\checkmark$ \\
\hline Povolené prečerpanie & $\checkmark$ & $\checkmark$ & $\checkmark$ & $\checkmark$ & $\checkmark$ & $\checkmark$ & $\checkmark$ \\
\hline Výpis z účtu (poštou) & $\checkmark$ & $\checkmark$ & $\checkmark$ & $\checkmark$ & $\checkmark$ & $\checkmark$ & $\checkmark$ \\
\hline $\begin{array}{l}\text { Mesačný poplatok za } \\
\text { vedenie účtu/balík služieb }\end{array}$ & $3,96 €$ & $4,90 €$ & $5,00 €$ & $3,29 €$ & $2,20 €$ & $3,99 €$ & $3,50 €$ \\
\hline
\end{tabular}

Zdroj: vlastné spracovanie podl'a obchodných podmienok a cenníkov porovnávaných bánk

Ako je zrejmé z Tabul'ky 2, najnižšie poplatky a d’alšie mesačné náklady súvisiace s vedením a spravovaním bežného účtu vynaloží klient Dexia banky. Poštová banka dosiahla v rebríčku vybraných bánk štvrté miesto. Najvyšší poplatok zaplatí klient Tatra banky. Porovnávané boli bežné účty, respektíve balíky služieb k bežnému účtu, ktoré zodpovedali 
požiadavkám modelového klienta. Poradie bánk však môže byt' iné v prípade, že klient splní podmienky pre uplatnenie bonusu či zl'avy z poplatku za vedenie účtu, ktoré sa pohybujú v rozpätí $25 \%$ až $100 \%$. Nakol'ko banky poskytujú rôzne zl'avy pri splnení rôznych podmienok, neboli tieto skutočnosti brané do úvahy.

Tabul'ka 3 Náklady a poplatky klienta súvisiace s používaním platobnej karty vo vybraných bankách v SR mimo balíka služieb

\begin{tabular}{|c|c|c|c|c|}
\hline & \multirow{2}{*}{$\begin{array}{l}\text { Poplatok za } \\
\text { platbu kartou } \\
\text { mimo balíka } \\
\text { služieb }\end{array}$} & \multicolumn{2}{|c|}{$\begin{array}{l}\text { Poplatky za výber z bankomatu } \\
\text { debetnou kartou v zahraničí }\end{array}$} & \multirow{2}{*}{$\begin{array}{l}\text { Poplatok za zmenu } \\
\text { limitu na karte }\end{array}$} \\
\hline & & Eurozóna & Svet & \\
\hline Poštová banka & $0,09 €$ & $1,33 €$ & $2 \% \min .5,49 €$ & $1,66 € / 3,32 €^{* * * *}$ \\
\hline Slovenská sporitel'ňa & $0,13 €$ & $1,26 €$ & $2 \% \min .5,31 €$ & $1,66 € / 0,83 €^{*}$ \\
\hline Tatra banka & $0,10 €$ & \multicolumn{2}{|c|}{$1,23 €$} & $5 € / 10 €^{* *}$ \\
\hline OTP Banka Slovensko & $0,15 €$ & $1,00 €$ & $1,5 \% \min .3,32 €$ & $0 € / 1,66 € / 3,32 € * * *$ \\
\hline Dexia banka & $0,10 €$ & \multicolumn{2}{|c|}{$1,33 €$} & $0 €$ \\
\hline UniCredit Bank & $0,10 €$ & $1,13 €$ & $2 \% \min .4,98 €$ & $3,32 €$ \\
\hline VÚB Banka & $0,15 €$ & $1,30 €$ & $1,5 \%$ min. $6,20 €$ & $0 €$ \\
\hline \multicolumn{5}{|c|}{$\begin{array}{l}\text { *Cez internetbanking } \\
\text { **pri urgentnej zmene do } 24 \text { hodín } \\
* * * \text { zadarmo cez internetbanking/telefón, } 1,66 \text { na pobočke pri elektronických platobných kartách, } \\
3,32 \text { embosované karty } \\
* * * * \text { Maestro/Mastercard }\end{array}$} \\
\hline
\end{tabular}

Výbery z bankomatov v zahraničí patria v SR medzi najdrahšie bankové služby. Cenovo prijatel'nejšie sú len výbery z bankomatov v krajinách eurozóny, kde banky môžu klientovi účtovat' poplatok maximálne vo výške poplatku prislúchajúcemu výberu z cudzieho bankomatu v SR, čo predstavuje maximálne 1,33 Eura. Niektoré banky pristúpili k zjednoteniu poplatkov za výber z bankomatu na celom svete (napr. vid' Tabul'ka 3: Tatra banka, Dexia banka). Výhodnejšie ako výber hotovosti z bankomatu v zahraničí, je priamo platba kartou prostredníctvom POS terminálov. Zahraničné platby sú spoplatnené rovnako ako platby na Slovensku, pričom klient, ktorý má takúto službu zahrnutú v balíku služieb, za takéto použitie karty v zahraničí už neplatí. V prípade, že klientovi aj na Slovensku banka účtuje každú platbu zvlášt', rovnako sú mu účtované aj platby v zahraničí. Poplatok sa pohybuje v rozpätí $9-15$ centov.

O stave bankového sektora vypovedá aj pobočková siet'. Ďalším sledovaným atribútom je teda dostupnost' klienta k bankovým službám a k hotovosti uloženej na bežnom účte. Na jednej strane na Slovensku pripadá na jednu banku v priemere 55 pobočiek, čo je po Španielsku a Grécku tretí najvyšší počet (priemer EÚ je 23) a na druhej strane počet obyvatel'ov pripadajúcich na jednu pobočku je po Českej republike, Estónsku a Pol'sku štvrtý najvyšší v EÚ, čiže približne 4412 obyvatel'ov (priemer EÚ je 2 297). Banky v SR majú v priemere nadštandardne rozvinutú pobočkovú siet', avšak vzhl'adom na to, že je ich málo, dokážu zabezpečit' len menej ako polovicu pobočiek pokial' ide o porovnanie podl'a počtu obyvatel'ov. Situácia je daná aj významom pobočiek pri poskytovaní služieb, kedy pripadá takmer rovnaký počet obyvatel'ov na jednu pobočku (napr. Švédsko), avšak rozdiel je vo využívaní iných distribučných kanálov a to predovšetkým internetu. [4] Pri porovnávaní vybraných bánk na slovenskom bankovom trhu, najhustejšiu siet' pobočiek má Slovenská sporitel’ňa $(24 \%)$ a VÚB banka (20\%). Naopak najnižší počet pobočiek má Poštová banka (2,9\%). Avšak vzhl'adom nato, že služby Poštovej banky sú dostupné v 1586 prístupových 
miestach Slovenskej pošty, a.s. možno Poštovú banku považovat' za subjekt s najhustejšou siet'ou pobočiek, pričom 3345 obyvatel'ov pripadá na jednu pobočku.

Podl'a údajov SBA bolo v roku 2009 na území SR k dispozícií 2310 bankomatov a v prevádzke bolo 35478 POS terminálov pre uskutočnenie platby pri nákupe. Najväčší podiel na sieti bankomatov v SR má Slovenská sporitel'ňa a to 29\% a VÚB Banka, ktorej podiel je $24 \%$.

Tabul'ka 4 Počet bankomatov v SR podl’a údajov Slovenskej bankovej asociácie

\begin{tabular}{|l|c|c|c|}
\hline & $\mathbf{2 0 0 7}$ & $\mathbf{2 0 0 8}$ & $\mathbf{2 0 0 9}$ \\
\hline Počet bankomatov v SR & 2154 & 2266 & 2310 \\
\hline Počet POS terminálov v SR & 26189 & 31722 & 35478 \\
\hline
\end{tabular}

Zdroj: vlastné spracovanie podl'a http://www.sbaonline.sk/sk/bankovy-sektor/statistika/

Tabul'ka 5 Počet pobočiek a bankomatov vybraných bánk v SR

\begin{tabular}{|c|c|c|c|c|c|c|c|}
\hline & 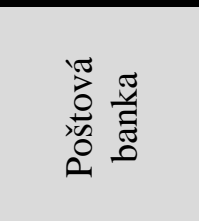 & 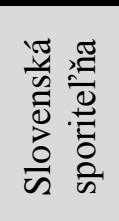 & 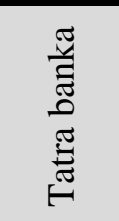 & 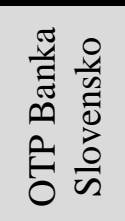 & 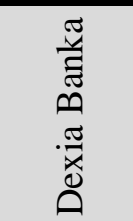 & 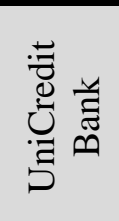 & 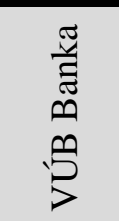 \\
\hline Počet pobočiek & $\frac{36}{1586 \text { pôšt }}$ & 297 & 148 & 77 & 49 & 81 & 243 \\
\hline $\begin{array}{l}\text { Počet obyvatel'ov na } \\
\text { pobočku* }\end{array}$ & 150740 & 18272 & 36667 & 70476 & 110748 & 66996 & 22332 \\
\hline \multirow[b]{2}{*}{ Počet bankomatov } & $\frac{3422}{114}$ & \multirow[b]{2}{*}{677} & \multirow[b]{2}{*}{328} & \multirow[b]{2}{*}{115} & \multirow[b]{2}{*}{86} & \multirow[b]{2}{*}{134} & \multirow[b]{2}{*}{558} \\
\hline & $\begin{array}{c}1100 \\
\text { poštomatov }\end{array}$ & & & & & & \\
\hline $\begin{array}{l}\text { Počet obyvatel'ov na } \\
\text { bankomat* }\end{array}$ & $\begin{array}{c}47602 \\
4933\end{array}$ & 8016 & 16545 & 47188 & 63101 & 40497 & 9725 \\
\hline$*_{\mathrm{K}} 31.3 .2010$ počet obyvat & $\frac{4933}{54266}$ & & Intol 1 & iscs & owdo & $2 d{ }^{2} i$ & 5654 \\
\hline
\end{tabular}

Porovnanie bánk na základe ponúkaných úrokových sadzieb vkladových produktov je pre klienta zaujímavé v prípade, že má vol'né hotovostné prostriedky. K zvyšovaniu úrokov pristúpili banky v závere minulého roka (2009), kedy sa končila ročná viazanost' termínovaných vkladov, ktorých väššina bola vložená pred prijatím eura. Vyššími úrokmi chceli banky sporitel'ov motivovat', aby svoje peniaze nechali na termínovaných vkladoch. Kým v októbri 2009 priemerný úrok pri vkladoch s viazanost'ou do jedného roka bol 1,30\% p.a., v decembri sa zvýšil na 1,88 \% p.a. a v januári 2010 na takmer dve percentá. Potom znovu úroky klesli. Nízke úroky však automaticky neznamenajú, že uložené peniaze sporitel'ov strácajú hodnotu. Inflácia je v súčasnosti ešte nižšia ako úroky v bankách, to znamená, že reálna hodnota peňazí sa zvyšuje. Vo februári banky pri vkladoch s viazanost'ou do jedného roka ponúkali v priemere úrok 1,68 \% p.a.. Inflácia v tom istom mesiaci dosiahla $0,4 \%$. V tabul'ke 6 je uvedený prehl'ad aktuálnych sadzieb pre úročenie bežných účtov a termínovaných vkladov porovnávaných bánk. Medzi bankami sú v súčasnosti pri úroční termínovaných vkladov takmer minimálne rozdiely, vyššie úroky väčšinou ponúkajú menšie banky. Výhodou termínovaných vkladov je, že úroková miera sa počas celej doby sporenia nemení a nové úroky sa vzt’ahujú len na nové vklady. Alternatívou k termínovaným vkladom a pružnejším produktom ako pre klienta tak i pre banku sú v súčasnosti sporiace účty, ktoré klienta nenútia ponechat' svoje peniaze po celý čas v banke. [9] 
Tabul'ka 6 Úročenie vkladov do 33000 EUR (\% p. a.) vo vybraných bankách v SR

\begin{tabular}{|c|c|c|c|c|c|c|}
\hline \multicolumn{7}{|c|}{ Úročenie osobných účtov (EUR) } \\
\hline & \multicolumn{2}{|c|}{ Kredit } & \multicolumn{2}{|c|}{ Povolený debet } & \multicolumn{2}{|c|}{ Nepovolený debet } \\
\hline $\begin{array}{l}\text { Poštová } \\
\text { banka }\end{array}$ & \multicolumn{2}{|c|}{0,01} & \multicolumn{2}{|c|}{$12,90 / 15,90$} & \multicolumn{2}{|c|}{20,00} \\
\hline $\begin{array}{l}\text { Slovenská } \\
\text { sporitel'ňa }\end{array}$ & \multicolumn{2}{|c|}{0,10} & \multicolumn{2}{|c|}{17,90} & \multicolumn{2}{|c|}{25,90} \\
\hline Tatra banka & \multicolumn{2}{|c|}{0,05} & \multicolumn{2}{|c|}{15,50} & \multicolumn{2}{|c|}{24,50} \\
\hline $\begin{array}{l}\text { OTP Banka } \\
\text { Slovensko }\end{array}$ & \multicolumn{2}{|c|}{$0,00-0,20$} & \multicolumn{2}{|c|}{$12,90 / 15,90$} & \multicolumn{2}{|c|}{20,00} \\
\hline Dexia banka & \multicolumn{2}{|c|}{0,05} & \multicolumn{2}{|c|}{16,90} & \multicolumn{2}{|c|}{20,00} \\
\hline $\begin{array}{l}\text { UniCredit } \\
\text { Bank }\end{array}$ & \multicolumn{2}{|c|}{0,10} & \multicolumn{2}{|c|}{$15,00 / 18,50$} & \multicolumn{2}{|c|}{30,00} \\
\hline VúB Banka & $0,10-$ & ,30* & $8,50 /$ & 3,90 & & \\
\hline \multicolumn{7}{|c|}{ Úročenie termínovaných účtov pre fyzické osoby (EUR) } \\
\hline & 1 mesiac & 3 mesiace & 6 mesiacov & 1 rok & 2 roky & 3 roky \\
\hline $\begin{array}{l}\text { Poštová } \\
\text { banka }\end{array}$ & $0,15-0,25$ & $0,30-0,50$ & $0,65-0,80$ & $1,20-1,40$ & $2,30-2,50$ & $2,80-3,00$ \\
\hline $\begin{array}{l}\text { Slovenská } \\
\text { sporitel’ňa }\end{array}$ & 0,15 & $0,30-0,35$ & $065-0,70$ & $1,00-1,10$ & 2,00 & 2,50 \\
\hline Tatra banka & $0,10-0,15$ & $0,25-0,30$ & $0,50-0,60$ & $0,90-1,00$ & 1,70 & 2,05 \\
\hline $\begin{array}{l}\text { OTP Banka } \\
\text { Slovensko }\end{array}$ & 0,25 & 0,30 & 0,80 & 1,20 & 2,30 & 2,90 \\
\hline Dexia banka & $0,10-0,20$ & $0,40-0,50$ & $0,90-1,10$ & $1,30-1,40$ & $1,90-2,10$ & 2,60 \\
\hline $\begin{array}{l}\text { UniCredit } \\
\text { Bank }\end{array}$ & 0,15 & 0,40 & $0,50 / 0,70$ & $0,80 / 1,00$ & $1,90 / 2,00$ & $2,30 / 2,40$ \\
\hline VÚB Banka & $0,10-0,15$ & $2,25-0,35$ & $0,55-0,65$ & $1,00-1,05$ & 2,00 & 2,40 \\
\hline \multicolumn{7}{|c|}{$\begin{array}{l}\text { *pri splnení určitých podmienok môže byt' zostatok do } 498 \text { EUR úročený sadzbou } 6 \% \\
\text { - Úrokové sadzby platné k 28.6.2010 }\end{array}$} \\
\hline
\end{tabular}

Z prehl'adu uvedeného v Tabul'ke 7 je zrejmé, že najvhodnejšou vol'bou pre získanie bezúčelového úveru je pôžička od Tatra banky. Avšak pri reálnom výbere je potrebné brat' do úvahy, že banky si účtujú poplatky za zriadenie a vedenie účtu (napr. Tatra banka: mesačný poplatok za vedenie účtu $2 €+$ jednorazový poplatok $2 \%$ ), ktoré sú závislé od objemu pôžičky a doby splácania úveru a naopak niektoré poskytujú úvery bez poplatkov (Poštová banka). Ďalším atribútom, ktorý môže rozhodnút' o reálne výhodnom úvere či už zabezpečenom alebo nezabezpečenom je bonita klienta a platobná schopnost', nakol'ko ako je zrejmé z Tabul'ky 7 , banky často krát stanovujú minimálnu a maximálnu úrokovú sadzbu, ktorou je úver zat’ažený.

Tabul'ka 7 Úročenie úverov pre fyzické osoby vo vybraných bankách v SR (\% p. a.)

\begin{tabular}{|l|c|c|}
\hline \multicolumn{3}{|c|}{ Bezúčelové úvery pre fyzické osoby } \\
\hline & Spotrebné úvery bez zabezpečenia & Kontokorent \\
\hline Poštová banka & $7,50-32,50$ & $16,90-20,90$ \\
\hline Slovenská sporitel'̌na & $9,90-17,90$ & 17,90 \\
\hline Tatra banka & $6,90-19,90$ & 15,50 \\
\hline OTP Banka Slovensko & $7,25-21,00$ & $12,90 / 15,90$ \\
\hline Dexia banka & $12,50-14,50$ & 16,90 \\
\hline UniCredit Bank & $6 \mathrm{MB}+(5,00-10,00)$ & $15,00 / 18,50$ \\
\hline VÚB Banka & $7,90-16,90$ & $8,50 / 16,90$ \\
\hline
\end{tabular}


Pokračovanie Tabul'ky 7

\begin{tabular}{|c|c|c|c|c|}
\hline \multicolumn{5}{|c|}{ Hypotekárne úvery pre fyzické osoby } \\
\hline & Variabilné & Pevné 5 rokov & Pevné 10 rokov & $\begin{array}{l}\text { Splatnost' } \\
\text { (roky) }\end{array}$ \\
\hline Poštová banka & & - & - & - \\
\hline Slovenská sporitel'ňa & $(4,09-6,79)^{1}$ & $\begin{array}{c}4,59-7,29 \\
(4,39-7,09)^{2}\end{array}$ & $5,29-7,99$ & $1-30$ \\
\hline Tatra banka & $(4,05-7,05)^{1}$ & $\begin{array}{c}4,75-7,75 \\
(4,35-7,35)^{2}\end{array}$ & $\begin{array}{c}6,19-9,19 \\
(5,75-8,75)^{3}\end{array}$ & $4-30$ \\
\hline OTP Banka Slovensko & $3,99-5,99$ & $\begin{array}{c}4,95-6,95 \\
(4,39-6,39)^{2} \\
\end{array}$ & $6,19-8,19$ & $4-30$ \\
\hline Dexia banka & $(4,00-6,61)^{1}$ & $\begin{array}{c}4,69-7,69 \\
(4,69-7,46)^{2}\end{array}$ & $6,35-8,98$ & $4-30$ \\
\hline UniCredit Bank & $\begin{array}{l}\text { 6MB/12MB+[2,80 - 4,60] } \\
(3,89-5,99)^{1}\end{array}$ & $\begin{array}{c}4,79-7,19 \\
(4,29-6,49)^{2} \\
\end{array}$ & $5,59-8,09$ & $4-30$ \\
\hline VÚB Banka & $(4,14-6,44)^{1}$ & $4,44-6,74$ & $5,24-7,54$ & $4-30$ \\
\hline \multicolumn{5}{|c|}{$\begin{array}{l}{ }^{1} \text { sadzba fixovaná na } 1 \text { rok, }{ }^{2} \text { sadzba fixovaná na 3roky, }{ }^{3} \text { sadzba fixovaná na } 15 \text { rokov } \\
\text { - úrokové sadzby platné k 28.6.2010 }\end{array}$} \\
\hline \multicolumn{5}{|c|}{$\begin{array}{l}\text { Zdroj: vlastné spracovanie podla http://financie.etrend.sk/banky/uroky-z-bezucelovych-uverov.html, } \\
\text { http://financie.etrend.sk/banky/uroky-z-hypotekarnych-uverov.html, web stránky porovnávaných } \\
\text { bankových subjektov }\end{array}$} \\
\hline
\end{tabular}

\section{Záver}

Najčastejším atribútom, ktorý klienti bánk hodnotia sú poplatky a náklady súvisiace so správou a vedením účtu, ale tiež úrokové sadzby na vkladových produktoch. Atribútov a kritérií pre porovnanie je však v skutočnosti omnoho viac, predovšetkým závisia od požiadaviek a nárokov klienta, ale tiež schopností a snáh jednotlivých bankových subjektov zasiahnut' výraznejšie do konkurenčného boja o klienta. V súčasnosti sa hovorí o základnom a pre retailové obchody garantovanom balíku služieb, ktorý má podl'a Vyhlášky MF SR č. 290/2010 Z.z. o rozsahu a spôsobe poskytovania platobných operácií v mene euro v rámci základného bankového produktu obsahovat' mesačne neobmedzený počet platobných operácií uskutočnených prostredníctvom internetbankingu alebo inej platobnej aplikácie elektronického bankovníctva, d’alej neobmedzený počet platobných operácií uskutočnených platobnou kartou u osoby, ktorá prijíma platobné karty, tri hotovostné platobné operácie a neobmedzený počet bezhotovostných platobných operácií mesačne uskutočnených platobnou kartou prostredníctvom bankomatov príslušnej banky alebo pobočky zahraničnej banky v rámci Európskeho hospodárskeho priestoru, jedna hotovostná platobná operácia a tri bezhotovostné platobné operácie mesačne uskutočnené v mieste, kde banka alebo pobočka zahraničnej banky vykonáva svoju činnost'. Jedná sa o operácie vykonávané v euro mene v rámci Európskeho hospodárskeho priestoru. [9] Vyhláška však pri vytvorení základného bankového produktu ponecháva bankám dostatočnú vol'nost' a tak nie je isté či pôvodný zámer, ktorým malo byt' okrem iného aj sprehl'adnenie služieb a ul'ahčenie porovnávania bude dosiahnutý. Spoplatnenie tohto produktu si majú určit' banky, čo by malo podl'a MF SR zabezpečit' dostatočné konkurenčné odlíšenie jednotlivých bankových subjektov v segmente bežných účtov. SBA a rovnako i NBS vzniesli zásadné pripomienky k tomuto produktu, ktorý považujú za príliš luxusný pre bežného „jednoduchého“ klienta. Vyhláška je účinná od 1.júla 2010, pričom banky majú na jej premietnutie do praxe čas tri mesiace. Po 1. októbri 2010 bude teda zrejmé, ako si banky poradili s touto situáciou a aké cenové rozdiely v ponuke základného bankového produktu trh prinesie. 


\section{Literatúra}

[1] MADLEŇÁK, R., BENECH, P.: História a súčasnost' elektronických platobných systémov na Slovensku. In: Pošta, Telekomunikácie a Elektronický obchod: elektronický odborný časopis zameraný na problematiku poštových a telekomunikačných podnikov a oblast' elektronického obchodovania. - ISSN 1336-8281. Roč. 2, č. 1 (2007), s. 6 - 16. Prístup: http://ks.utc.sk/casopis/pdf/I2007/madlenak_benech.pdf.

[2] MIČEKOVÁ, M. A KOL.: Bankovníctvo : bankové operácie. - 1. vyd. - V Žiline : Žilinská univerzita, 2006. - 170 s., AH 13,18, VH 13,65 : - ISBN 80-8070-503-8.

[3] Slovenská banková asociácia: Porovnanie ročných nákladov na vedenie bežných účtov vo vybraných krajinách za rok 2009

[4] http://www.nbs.sk/img/Documents/Dohlad/ORM/Analyzy/2009-2.pdf

[5] http://www.sbaonline.sk/sk/bankovy-sektor/statistika/

[6] http://financie.etrend.sk/investicie.html

[7] http://portal.statistics.sk/showdoc.do?docid=5654

[8] http://www.zbierka.sk/default.aspx (Vyhláška MF SR č. 290/2010 Z.z. o rozsahu a spôsobe poskytovania platobných operácií v mene euro v rámci základného bankového produktu)

[9] web stránky porovnávaných bankových subjektov:

- http://www.pabk.sk/sk/osobne-financie/ucty/baliky-sluzieb

- http://www.slsp.sk/

- http://www.tatrabanka.sk/cms/

- http://www.otpbank.sk/

- http://www.dexia.sk/www/home.nsf/s/1001

- http://www.unicreditbank.sk/index.php

- http://www.vub.sk/osobne-financie/ 